\title{
Drugs: The Portuguese fallacy and the absurd medicalization of Europe
}

\section{Drogas: a falácia portuguesa e a "medicalização" absurda da Europa}

Manuel Pinto Coelho ${ }^{*}$

CARTA AO EDITOR | LETTER TO THE EDITOR

\section{Dear editor,}

In the early Spring of 2009, Mr. Glenn Greenwald (Greenwald, 2009), an American lawyer and author, fluent in Portuguese, was invited to Portugal to undertake an assessment of the results of the Portuguese drug decriminalization policy. The funding for this work was provided by the Cato Institute - a Washington DC based libertarian think-tank well known for its radical campaigns on drug policy. Mr. Greenwald stayed in the country for 3 weeks. The report based upon his visit presented Portuguese drug policy as an unparalleled success and an example for the world to follow. Greenwald's report for the Cato Institute has been widely cited in political, professional and media debate around the world, however, a key question to be addressed is whether the information and evidence contained within the report presents an accurate picture of the Portuguese experience. As I will show in this paper the answer to that question is a resounding "no" it does not present an accurate picture of the situation in Portugal and Portugal certainly does not stand as a beacon of the claimed benefits of drugs decriminalization.

The report produced by Greenwald contains a number of bold claims, including:

"The total number of drug-related deaths has actually decreased from the pre-decriminalization year of 1999 (when the total was nearly 400) to 2006 (when the total was 290)."

"Prevalence rates (for drug abuse) for the age group from 15 to 19 have actually decreased in absolute terms since decriminalization."

"Most significantly, the number of newly reported cases of HIV and AIDS among drug addicts has declined substantially every year since 2001."

In the light of these claimed positive outcomes a number of influential and highly respected publications have reported the fact that many countries are looking to replicate the Portuguese drugs decriminalization policy. The UK Guardian Newspaper for example reported on September 5 of 2010- "Britain looks at Portugal's success story over decriminalizing personal drug use" (Beaumont, Townsend, \& Helm, 2010); The Economist on August 27 of 2009 - "The evidence from Portugal since 2001 is that decriminalization of drug use and possession has benefits and no harmful sideeffects" (The Economist, 2009); and the Portuguese newsmagazine Visão on May 7 of 2009 - "Portugal inspires Obama" (Fernandes, 2009).

Greenwald's account however presents a highly partial and inaccurate picture of the situation within Portugal. Gil Kerlikowske, Director of the US Office of National Drug Control Policy, in a letter (Kerlikowske, 2010)

\footnotetext{
Letter received October $17^{\text {th }}, 2014$

${ }^{1}$ Manuel Pinto Coelho, MD, PhD, graduated in 1972 in Medicine and Surgery - Medical University of Lisbon, and holds a Ph. D in Educational Sciences by University of Trás-os-Montes and Alto Douro, Vila Real, Portugal.

* Corresponding author. Gaveto da Av. 25 de Abril, R. José Carvalho de Araújo n 262, $3^{\circ}$ piso, sala 20 - Edifício Regata, 2750-396 Cascais, Portugal E-mail: info@doutorpintocoelho.pt
} 
Oto a member of the International Task Force on Strategic Drug Policy and Drug Watch International, has stated that:

“... after a careful review of all available data on this subject....our analysts found that claims that decriminalization has reduced drug use and had no detrimental impact in Portugal significantly exceed the existing scientific basis. This conclusion largely contradicts the prevailing media coverage and several policy analyses made in Portugal and in the United States." (Kerlikowske, 2010)

The letter from Kerlikowske concluded:

“Drug Legalizers' Claims Exceed Supporting Science - In addition to the complications associated with using lifetime prevalence data to assess the impact of drug policies, and to the challenges presented by evidence that is not fully considered in the Cato Institute report, it is generally difficult to be certain whether shifts in drug-related results in Portugal and other countries are due to changes in drug policy or to other factors." (Office of National Drug Control Policy, 2010)

According to the US Drug Czar the claimed benefits of the policy of drugs decriminalization in Portugal have been exaggerated by those seeking to promote the policy drugs decriminalization when in reality a good deal more information is required on the impact of that policy within Portugal before any persuasive case can be made for the wider replication of the Portuguese policy. In the remainder of this paper I discuss some of the additional data that is now available which reveals a very different picture of what has happened within Portugal to the image contained within Greenwald's Cato Institute report.

In relation to drug related deaths for example, further data provided by the European Monitoring Centre for Drugs and Drug Addiction, have revealed not a marked reduction in mortality but a notable increase in the number of deaths recorded following the implementation of the policy of drug decriminalization:
Drug-induced deaths in Portugal, which decreased from 369 in 1999 to 152 in 2003, rose to 314 in 2007 - significantly more than the 280 deaths recorded when decriminalization started in 2001" (European Monitoring Centre for Drugs and Drug Addiction, 2008).

In relation to Greenwald's claimed reduction in the prevalence of drug use amongst young people in Portugal following decriminalization other data have shown a notable increase in the rates of drug use for certain age groups:

"[...] the report makes claims about Portuguese drug legalization success. However, it proclaims a decline in the lifetime prevalence rate for the 15-19 age group between 2001 and 2007, while disregarding a larger lifetime prevalence increase in the 15-24 age group and ignoring the substantially larger lifetime prevalence increase in the 20-24 age group over the same period (Greenwald, p.14). Furthermore, the report emphasizes decreases in lifetime prevalence rates for the 13-18 age group between 2001 and 2006 and for heroin use in the 16-18 age group from 1999 to 2005, but once again downplays increases in the lifetime prevalence rates for the 15-24 age group between 2001 and 2006, and for the 16-18 age group between 1999 and 2005." (Greenwald, 2009, pp. 12-14).

Despite an assertion in the Cato Institute report that increases in lifetime prevalence rates for the general population are 'virtually inevitable in every nation', EMCDDA data indicate that several countries have been able to achieve decreases in lifetime prevalence rates (including Spain) for cannabis and ecstasy use between 2003 and 2008" (European Monitoring Centre for Drugs and Drug Addiction, 2010).

Within the Cato Institute report Greenwald concentrates on the drug prevalence data for the 15 to 19 year old age range whilst making only passing reference to the older 20 to 24 age range where in fact there has been a $50 \%$ increase in rates of drug use. In figure 1 below data from the Instituto da Droga Toxicode- 
pendência de Portugal reveal an increase in lifetime drug use prevalence for each of the age range presented. Similarly in Figure two there has been a notable increase in drug prevalence for each of the substances noted with cannabis consumption increasing 150\% from 2001 to 2007 and only a slight decrease in 2006.

There is only a slight decrease in 2006 (with the exception of heroin). Although subsequent years' numbers are still not available, there is a general consensus that the figures are still mounting: if we pay attention to the data of the group under 34, we can confirm an escalation of almost $50 \%$.

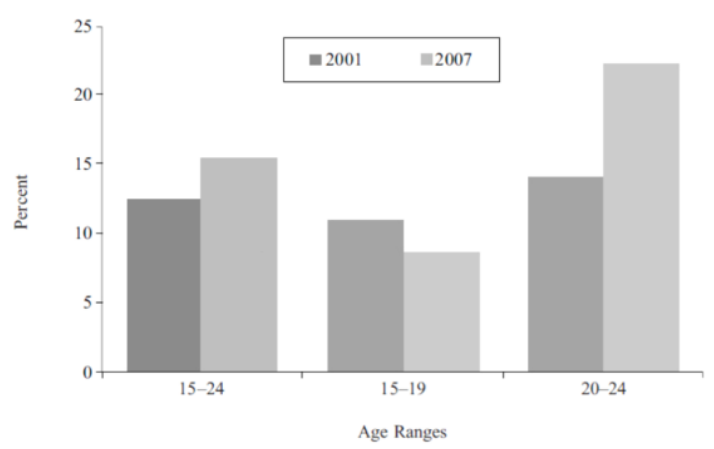

Figure 1. General Population, 2001-2007 Lifetime Prevalence (Instituto da Droga e da Toxicodependência, 2007)

Looking at the numbers related to the prevalence in the Portuguese population (figures 2 and 3), there isn't a single drug consumption category that has decreased since 2001.

Between 2001 and 2007, the drug consumption in Portugal increased by $4.2 \%$ in absolute terms - the percentage of people who have experienced drugs at least once in their lifetime climbed from $7.8 \%$ in 2001 to $12 \%$ in 2007 (Instituto da Droga e da Toxicodependência, 2007).

The prevalence of selected drug use for the 15 to 34 age range in Portugal is illustrated below comparing years 2001 to 2007 (Instituto da Droga e da Toxicodependência, 2007):

- Cannabis: from $12.4 \%$ to $17 \%$ (15-34 years old)

- Cocaine: from $1.3 \%$ to $2.8 \%$ (15-34 years old)
- Heroine: from $0.7 \%$ to $1.1 \%$ (15-64 years old)

- Ecstasy: from $1.4 \%$ to $2.6 \%$ (15-34 years old)

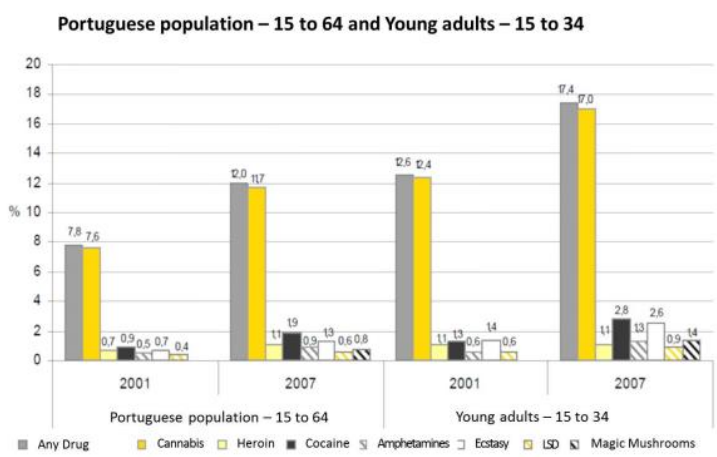

Figure 2. Lifetime Prevalence According to the Type of Drug (Instituto da Droga e da Toxicodependência, 2008)

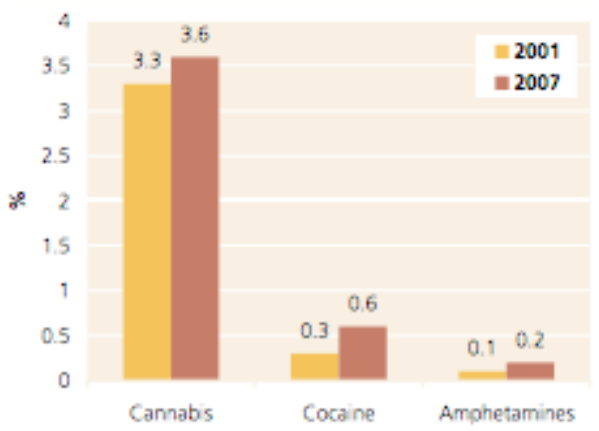

Figure 3. Annual Prevalence for adult drug use (15-64) 2001-2007 (European Monitoring Centre for Drugs and Drug Addiction, 2008).

In relation to Cannabis use the European Monitoring Centre for Drugs and Drug Addiction have noted that:

"It is difficult to assess trends for the intensive cannabis use in Europe, but among the countries that participated in both field trials between 2004 and 2007 (France, Spain, Ireland, Greece, Italy, Netherlands and Portugal), there was an average increase of approximately 20\%." (European Monitoring Centre for Drugs and Drug Addiction, 2008).

In relation to Cocaine the EMCDDA have pointed out that: 
"There still remains a notorious growing consumption of cocaine in Portugal, although not as severe as what is verifiable in Spain. The increase in consumption of cocaine is extremely problematic." (Gotz, 2009).

Within the 2008 Annual Report of the EMCDDA it is noted that "Trends of cocaine use", the new data (surveys from 2005-2007) confirms the escalating trend in France, Ireland, Spain, United Kingdom, Italy, Denmark, and Portugal (European Monitoring Centre for Drugs and Drug Addiction, 2008). While amphetamines and cocaine consumption rates doubled in Portugal, cocaine drug seizures increased sevenfold between 2001 and 2006 (figure 4), rating this country as the sixth highest in the world (United Nations Office on Drugs and Crime, 2010).

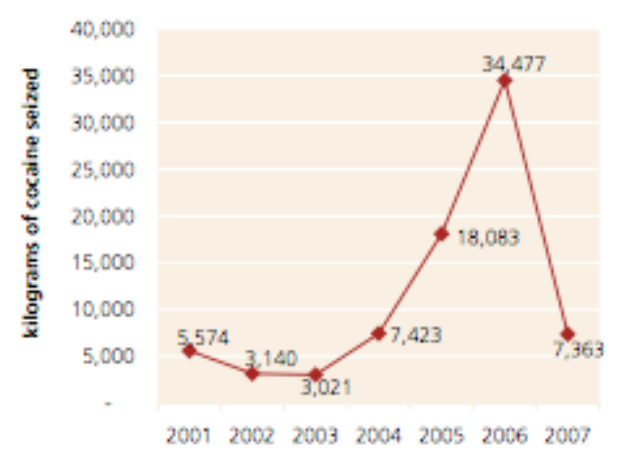

Figure 4. Kilograms of cocaine seized in Portugal, 2001-2007 (United Nations Office on Drugs and Crime, 2009)

\section{Heroin and Drug related Deaths and Homi- cides}

In Portugal, heroin is the drug most responsible for confinement in drug rehabilitation facilities and for overdose deaths. Second to Luxembourg, Portugal has the highest rate of consistent drug users and IV heroin dependents (Instituto da Droga e da Toxicodependência, 2007). Concerning drug-related deaths, Portugal recorded 219 in 2005, representing an increase of $40 \%$ when compared to 2004, when 156 people died (Instituto da Droga e da Toxicodependência, 2007). In 2006, the total number of deaths caused by drug overdose did not diminish radically when compared to 2000 . In fact, it was the opposite.

"With 219 deaths due to drug 'overdose' per year, Portugal has one of the worst records in Europe, reporting more than one death every two days. Along with Greece, Austria and Finland, Portugal is one of the countries that recorded an increase in drug overdose deaths by over $30 \%$ in 2005." (European Monitoring Centre for Drugs and Drug Addiction, 2007).

In 2007 , the number of deceased individuals that tested positive for drugs at the Portuguese Institute of Forensic Medicine was 314, which represented a $45 \%$ rise since the previous year: 216. This represents the highest numbers since 2001 - roughly one death per day -, therefore reinforcing the growth of the drug trend since 2005 (figure 5).

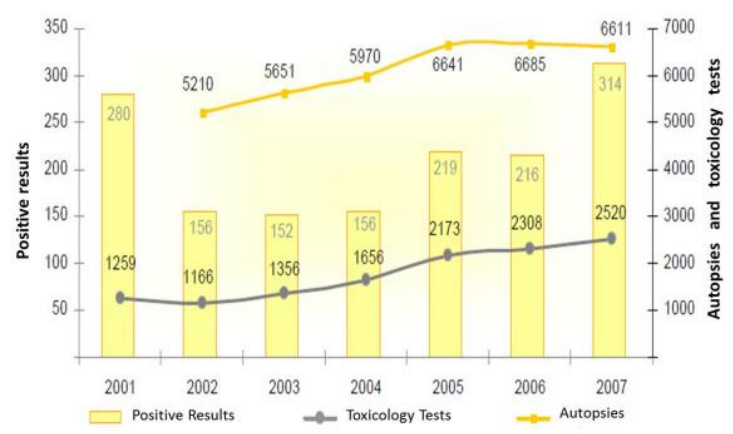

Figure 5. Toxicology tests and autopsies, and their relation to positive results on drugs. Source: Forensic Institute of Portugal

Since decriminalization was implemented in Portugal, the number of drug related homicides has increased by $40 \%$ (United Nations Office on Drugs and Crime, 2010), again according to the European Monitoring Centre for Drugs and Drug Addiction Portugal:

“..was the only European country with a significant increase in [drug-related] murders between 2001 and 2006." (European Monitoring Centre for Drugs and Drug Addiction, 2010). 


\section{HIV and AIDS}

In relation to HIV and AIDS, far from the picture of a clear decline there is evidence of the opposite occurring within Portugal following decriminalization.

"The highest HIV/AIDS mortality rates among drug users are reported for Portugal, followed by Estonia, Spain, Latvia and Italy; in most other countries the rates are much lower." (European Monitoring Centre for Drugs and Drug Addiction, 2007).

Portugal remains the country with the highest incidence of related intra-venous use drugs with AIDS and it is the only country recording a recent increase. 703 newly diagnosed infections, followed by Estonia with 191, and Latvia with 108 reported cases (European Monitoring Centre for Drugs and Drug Addiction, 2007, p. 82). The number of new cases of HIV/AIDS and Hepatitis C in Portugal recorded among drug users is eight times the average of other countries of the European Union (European Monitoring Centre for Drugs and Drug Addiction, 2007). According to the Portuguese Ministry of Health:

"Portugal keeps on being the country with the most cases of injected drug related AIDS infections (85 new cases per million of citizens in 2005, while the majority of other EU countries do not exceed 5 cases per million) and the only one registering a recent increase. 36 more cases per million of citizens were estimated in 2005 comparatively to 2004 , when only 30 were referred." (European Monitoring Centre for Drugs and Drug Addiction, 2007, p. 82).

\section{In short:}

"Portugal' s drug policy - as with all other national drug policies - is unlikely to be a "magic bullet". The country still has high levels of problem drug use and HIV infection, and does not show specific developments in its drug situation that would clearly distinguish it from other European countries that have a different policy" (European Monitoring Centre for Drugs and Drug Addiction, 2011, p. 24).
"The impact of the law that decriminalized drug use in Portugal confirms the result of the most anticipated experiences of decriminalization: - has little or no effect on drug use and addiction. The decriminalization of consumption does not interfere decisively in the evolution of consumption indicators" (Quintas, 2013 Apresentação da análise da experiência portuguesa da descriminalização do consumo de drogas, na Assembleia da República, pelo "Grupo de Trabalho Toxicodependência e Álcool).

Finally, Portugal where every citizen may carry out in his pocket any drug at all from cannabis derivate to heroin and crack cocaine until 10 days that is considered for personal use and sanctioned only with a pecuniary fine, banned the production import export advertising distribution sale and provision of the New Psychoative Substances in it's entire territory (DL 54/2013, 2013 Prevenção e proteção contra a publicidade e comércio das novas substâncias psicoativas) today's world's number one thrill accordingly the recent June 26 2013 World Drug Report.

So accordingly the recently released legislation, referring the so called smartshops, all "stores that sell the so called "legal highs" are forced to close".

"Is an important step in responding to an alarming phenomenon" stated the Secretary of State of Ministry of Health Fernando Leal da Costa.

Accordingly the new Decree-Law "Is prohibited each and every activity, continued or isolated, production, importation, exportation, advertisement, distribution, possession, sale or simple delivery of the new psychoactive substances. Is also determined the closure of places used for such purposes" one may read in a statement issued after this afternoon meeting of the Government.

The new substances covered by the new diploma are those that "in pure form or in a preparation can be a threat to public health compared with the substances already listed in legislation". 
In this new list are 48 phenylethylamines, 33 cathinone derivates, 36 synthetic cannabinoids, 4 cocaine derivatives / analogues, 5 plants and respective constituent assets and 12 miscellaneous items, including fertilizers and fungi.

The new law provides for a gradual upgrade of the substances to ban.

"In this moment we did already identified 159" Fernando Leal da Costa stressed, adding that the update will be made for periods not exceeding 18 months and "whenever there is a need.

This law thus gives answer to the problems associated with the use of new psychoactive substances, which have been developed at an increasing rate and that are not included in the ban substances lists on United Nations Conventions, transposed into Portuguese law", refers the document just released. (http://www.theportugalnews.com/news/smart shop-drugs-to-be-illegalised/27524)

\section{Decriminalization and CDTs}

"In July 1st 2001, Portugal drug law changed. The Law 30/2000 was adopted, decriminalizing the use, acquisition or possession of all illicit drugs once proven that the substance is only for personal consumption. Before that, illicit drug possession, acquisition, and use were considered criminal offenses punishable by fines or up to 3 months in prison. Possession of more than 3 daily doses of an illicit drug increased the maximum prison term up to 1 year [...] After July 2001, the possession of illicit drugs remained prohibited, and the cultivation or trafficking of illicit drugs remained a criminal offense. However the consumption, purchase, and possession of illicit drugs for personal use - defined as the quantity for a period of consumption of 10 days for one person - became administrative offenses to be referred to Commissions for the Dissuasion of Drug Addiction instead of the Portuguese criminal justice system." (Kerlikowske, 2010).

In other words, this means that whilst it remains illegal to sell purchase and consumed drugs in Portugal citizens will never be crimi- nally charged for any type of drug-related crime, unless they possess a higher quantity than what is estimated for a 10 day supply (figure 6).

\section{Law decriminalizes every single drug}

Q Up to the following quantities:

$\begin{array}{ll}25 \text { grams } & \Rightarrow \text { Cannabis } \\ 2 \text { grams } & \Rightarrow \text { Cocaine } \\ 1 \text { gram } & \Rightarrow \text { Heroin } \\ 5 \text { grams } & \Rightarrow \text { Hashish } \\ 5 \text { pills } & \Rightarrow \text { Extasis }\end{array}$

Figure 6. Amount of drugs for a 10 day supply according to the Portuguese law

With the new Portuguese law, the drug dependent is no longer a criminal, but a sick individual requiring treatment of his 'disease'.

The belief on the part of the architects of the Portuguese drug policy was that by eliminating the social stigma associated with criminalized drug consumption, the drug dependents could be more easily attracted to enroll in drug dissuasion programs. This idea is based on the view that most drug dependents' avoid treatment due to their fear of criminal charges. In an article dedicated to Portugal's drug policy, The Economist, in one of its printed editions, states: "Officials believe that, by lifting fears of prosecution, the policy has encouraged addicts to seek treatment. This bears out their view that criminal sanctions are not the best solution. 'Before decriminalization, the addicts were afraid to seek treatment because they feared they would be denounced to the police and arrested,' says a deputy director of the Institute for Drugs and Drug Addiction, Portugal' s main drugs-prevention and drugs-policy agency. 'Now they know they will be treated as patients with a problem, and not stigmatized as criminals'." (The Economist, 2009).

The image of Portugal which has been presented within reports such as that from the Cato Institute is one in which the drug user is 
not seen as a criminal but as someone who is suffering from a medical condition. However the distinction between those selling drugs and those using drugs in Portugal is by no means easy to maintain. According to the INA - Instituto Nacional de Administração (National Institute of Administration) which was given the responsibility for assessing the impact of the National Strategy Against Drugs "it is very hard to distinguish between dealer and consumer, since it is very easy for a dealer to organize his distributing method with smaller quantities, which don't stand as a crime offense" (Tavares, Graça, Martins, \& Asensio, 2004).

Since this neutral report was published in 1999, until today, very little has been done to improve the situation. And despite the disappointing results, the Portuguese strategy was renewed up until 2012. Within Portugal now there is a growing sense of fearlessness on the part of those selling small quantities of drugs, since most police officers don't think it is worthy of their time to arrest drug sellers. The impression of individuals being allowed to sell small quantities of drugs is very evident to anyone walking through the crowded streets of Lisbon's Cova da Moura ou Mouraria or through other areas in the city where more often than not they will be approached by individuals with hashish, cocaine and other drugs to sell, sometimes in broad daylight. This situation was nonexistent five years ago in such places (Audibert \& Araujo, 2009).

Another part of the Portuguese drug policy was the creation of CDT (Commissions for the Dissuasion of Drug Addiction). When users are caught in the act, they are sent to CDTs for evaluation. If justified, they are persuaded to follow some treatment in order to avoid administrative fines and other light penalties. In order to understand a little more about of this, we can read more statistical insight about the CDT:

Within the 2008 Activities Report (Instituto da Droga e da Toxicodependência, 2009, p. 55) from a total number of 7.346 processes appointed to deal with users, 2.816 of them were classified as being non-dependents, 2.075 still pending evaluation, and 783 considered to be dependents. Of these 783, 661 voluntarily accepted to be treated in order to temporarily suspend the legal process. From this group of 661 people, 166 never had any prior contact with treatment facilities, 127 that resumed treatment had already abandoned it before, and 368 were already following treatment when they got caught practicing the legal offense. (Instituto da Droga e da Toxicodependência, 2009). On this basis it would appear that the CDT teams, operating in every district in the country, with a total of 99 technicians, only managed to lead 166 addicts toward treatment, since the remaining $(127+368)$ were already referred and being followed in non-emergency medical facilities (CAT) (figure 7).

The danger here is one of interpreting the statistics on referrals as indicating the success of the CDT initiatives when in reality a substantial proportion of those coming into this system are already in contact with treatment facilities.

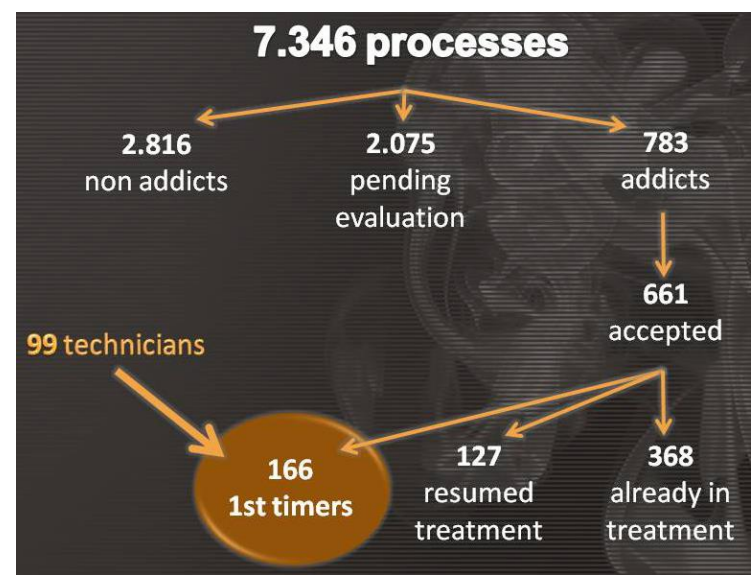

Figure 7. Activities Report - CDT (Instituto da Droga e da Toxicodependência, 2009)

\section{The medicalization of Europe}

Anand Grover, the United Nations Special Rapporteur on the Right of Everyone to the Highest Attainable Standard of Physical and Mental Health, in a 25 page report presented at the United Nations' General Assembly in New 
York on October 26, 2010, recommends Governments to:

"Ensure that the rights of people who use drugs are respected, protected and fulfilled"; "ensure that all harm-reduction measures (as itemized by UNAIDS) and drug-dependence treatment services, particularly opioid substitution therapy, are available to people who use drugs, in particular those among incarcerated populations"; "create a permanent mechanism with the necessary protection of the health and human rights of drug users and the communities they live in as its primary objective"; "take a human rights-based approach to drug control, and devise and promulgate rights-based indicators concerning drug control and the right to health"; "decriminalize or de-penalize possession and use of drugs." (United Nations General Assembly, 2010).

Quite surprisingly this high-ranking official highlighting two important issues - health and human rights - is revealing that he was not able to resist to the pressure and seem to have surrendered. Unexpectedly, his report came out coincidently while notorious prolegalization organizations, like Drug Policy Alliance, Cato Institute, Transnational Institute, Beckley Foundation, Encod, among others claim that the war on drugs can never be won and that a crime committed by someone on drugs can't be considered as an offence but as indicative of the individual having a health problem.

Very recently, on November 10, 2010, the EMCDDA released its Annual Report signed by its Chairman and its Director, respectively João Goulão (the Portuguese SICAD - Serviço de Intervenção nos Comportamentos Aditivos e Dependências, Director and Portuguese Drug Policy Coordinator) and Wolfgang Gotz. In this important document we can read:

"The estimated 1 million people now undergoing drug treatment testifies the work that has been done to ensure that care is made available to those in need [...]. Opioid substitution treatment remains the biggest sector in this area, and here the concerns appear to be changing, with questions being asked about the long-term results of those under care." (European Monitoring Centre for Drugs and Drug Addiction, 2010, p. 5).

"Overall, the EMCDDA estimates that about 670.000 Europeans now receive opioid substitution treatment, representing about half of the estimated number of problem opioid users." (European Monitoring Centre for Drugs and Drug Addiction, 2010, p. 17).

"Substitution treatment is the predominant treatment option for opioid users in Europe." (European Monitoring Centre for Drugs and Drug Addiction, 2010, p. 31).

"The general European trend is one of growth and consolidation of harm-reduction measures." (European Monitoring Centre for Drugs and Drug Addiction, 2010, p. 32).

"Putting science into practice in drug treatment: drug treatment has often been lethargic about adopting scientifically tested methods in its clinical practice. The limited provision of opioid substitution treatment in several European countries and the rare use of contingency management for the treatment of cocaine dependence are examples of this gap between science and practice." (European Monitoring Centre for Drugs and Drug Addiction, 2010, p. 48).

"Opioid substitution treatment, combined with psychosocial interventions, was found to be the most effective treatment option for opioid users." (European Monitoring Centre for Drugs and Drug Addiction, 2010, p. 78).

"Deaths showing the presence of substances used in opioid substitution treatment are also reported each year. This reflects the large number of drug users undergoing this type of treatment and does not imply that these substances were the cause of death. Overdose deaths among clients in substitution treatment can be the result of combining drugs, as some treatment clients still use street opioids, engage in heavy drinking and use prescribed psychoactive substances. However, most deaths due to substitution substances (often in combination with other 
substances) happen among people who are not in substitution treatment (Heinemann et al. 2000)." (European Monitoring Centre for Drugs and Drug Addiction, 2010, p. 86)

The model of society (concerning narcotic dependence) that used to strive for drug free and viewed drug dependence as unacceptable and marginal, appears not to have given way to a completely different model, promoted by representatives of the United Nations and Europe: one that considers the idea of a utopian drug-free society as unrealistic.

\section{Health}

In contrast to the suggestion that we should place health at the centre of drug policy there is a strong case instead for placing "well being" at the centre of polcy. Viewing drug dependency as a 'treatable health condition' is a way to call it a disease, as labeled by ED countless times: "drug addicts need treatment as much as patients of chronic diseases such as cancer, diabetes and tuberculosis." (United Nations Office on Drugs and Crime, 2009). But what does treatment in this context actually mean?

Maintaining a lifetime chemical dependency is considered a treatment? Can we interpret the 700,000 Europeans, representing about half of the estimated number of opioid users in all Europe (and now on opioid substitution programs), as being in treatment? Can we interpret the massive $70 \%$ majority of dependents on opioid substitution programs in Portugal to be an indicator of success? Can drug dependents aspire to a life free of drugs? Can a drug-free treatment lead to this goal? The fundamental question is, must the drug dependent be a condemned victim of his own biology or can he overcome the problem when he becomes aware of it?

Based on this assumption, harm reduction strategies are used as the main tool to fight drug dependency, as we see by consulting both EMCDDA 2010 and 2011 Annual Reports. This is confirmed by the abnormal percentage of drug dependents in substitution programs - more than a half of all European opioid dependents in treatment. In political terms, this also means that the well intentioned officials, like the Portuguese and many others in Europe, realize that curing drug dependents is indeed a very difficult task. The majority of them relapse many times when they try to stop using drugs. The position of João Goulão, president of EMCDDA and Portuguese SICAD director, can be seen in some of his statements:

"The heroic attempt to stop addiction to heroin does work in some cases, but rarely. The diabetics need insulin, some people need an opiate - more and more scientific evidence suggests this. There is, in the very sensitive area of brain receptors, a deficit that is installed in the production of certain chemical mediators, which requires that these people need an opiate to achieve a socially, family and professionally well integrated life. Very often, when trying to stop, these addicts give up and return to consumption, demolishing all the work already achieved. Hence, the IDT prefers to keep the users in programs that work for the discontinuity of these treatments." (Maia, 2009).

It would seem that UNODC's 2008 slogan, "use music, use sports, do not allow drugs to come into your life" was replaced in Portugal and other European countries, in a symbolic way, by something like "use methadone, use buprenorphine, don't allow drugs to abandon your life". But what is the alternative and does abstinence work?

Even if drug therapists do not teach that abstinence and spontaneous remission are very frequent occurrences, a well-known and reputed study revealed that people who successfully completed a treatment program (in some cases, one year after the beginning of abstinence) reduced their illicit activities by $60 \%$. The drug trades fell almost $80 \%$, imprisonment decreased more than $60 \%$, homeless drug dependents decreased almost $43 \%$, dependence on Social Institutions fell $11 \%$ and employ- 
ment increased 20\% (Leshner, 1997). By transferring the problem to the medical profession, politicians have successfully managed to transform political problems into medical ones requiring specialized medical intervention. This deprives society of the responsibility to correctly and accurately research the true causes of entering and exiting drug dependency.

Medicine takes care of the consequences of drug dependence, but may not explain how people get into it. This points to the idea that drug dependents need psychological help, not medical: while medical doctors prescribe medicines, psychologists 'prescribe' psychotherapy. Psychologists are essential in this process, by providing fundamental emotional control strategies and skills so that people understand how to avoid the situations that usually lead to drug abuse.

The following quote from an official of one of the most prestigious world drug dependence Centers, San Patrignano, in Italy, reiterates this idea:

"Many countries' social policies reflect the belief that drug addiction is a disease and that relapse is inevitable. Believing that it is impossible to cure addiction, the general goal became the reduction of social harm, by the stabilization of drug addicts rather than their full rehabilitation, with the illusion that this is also the more convenient option in a financial point of view. Even when accounting only the direct costs of drug addiction, such as methadone distribution, needle exchange and everything for medical, psychiatric and legal assistance, the expense is enormous: in 2005 Italy spent 800 million euros, France spent 1000 million, and the United Kingdom almost 2000 million. With 2000 million euros, in one year we could have placed 41,600 people into San Patrignano's program. Four years later, 31,200 of these people would have been fully recovered and living their lives free of drugs. But with the actual situation, these 41,600 can only be multiplied over and over again into an ever increasing number of individuals subsisting on replacement therapies and revolving clinic and prison doors." (Luppi \& Barzanti, sem data).
To further support this idea through science, an important study led by Neil McKeganey, director of the Scottish Centre for Drug Misuse Research, focusing on Scottish drug dependents reality, says, "[...] almost $60 \%$ of individuals said that abstinence was the only goal that they were seeking to achieve [...] on the whole drug users contacting drugtreatment services in Scotland tend to be looking for abstinence rather than harm reduction as the change they are seeking to bring about." (McKeganey, Morris, Neale, \& Robertson, 2004).

On the other hand, a wide range of life situations, such as deaths of relatives or close friends, relationship break ups, difficulties at work, drug dependence, or sexual abuse have been transformed into chemical problems. The human being, with his own life history and uniqueness, in this way is reduced into a biochemical entity - in many cases, just missing what life is about. The message that drugs can heal our problems has profound consequences. It encourages people to perceive themselves as helpless victims of their own biology. As a result, drug dependents all over the world, with the support of tax payers, keep on getting the message that they are sick, and the governments keep on trying to treat them.

There is the need for a new paradigm about drug dependency: the creation of a culture of caring, a culture where one should look at the drug dependent instead of looking at the drug dependency. A new paradigm which holds a different understanding of drug dependence, an alternative model which maintains that this is not a chronic disease, recurrent and progressive, but instead "the result of a complex interaction between culture, immediate environment, individual availability and substance" (Peele, 1985).

The focus should be directed to individual health, with its social, familial, economic and psychological idiosyncrasies, thus switching from the one size fits all model and returning to the model tailored to the individual that 
protects the uniqueness of each person.

\section{Human rights}

Before we start to discuss the problem of human rights, the first question should be: from what point of view should we address this controversial subject?

Sandra, a former drug dependent, one among millions in drug rehabilitation centers throughout this world, gave her personal perspective on this subject: "If it was not so troublesome to be a drug dependent, I am sure that I would not have cured myself. If I knew that it was easy for me to get my drug of choice without any worries, I am positively convinced that I would not be able to stop using it ever. Drugs are like that." (Sandra, 2004).

Addressing the question: in a free society, should people do whatever they want with their bodies since they don't harm others? The answer should be no. If someone starts on drugs, he is free; once he gets dependent, he loses that freedom. The consumption becomes imperative, at all costs, often subverting the rules of society in the process. To the alcoholic or to the drug dependent, the surrounding environment, which includes their partner, children, neighbors, friends, co-workers, everyone with whom he has any kind of relation, will be affected by his drug dependent behavior. The suffering of the families is often greater than his. Their sorrow, due to the dependent's problem, is exacerbated by legal and criminal matters.

As it was said by the father of modern liberalism, the English philosopher John Stuart Mill (1806-1873) in his classic "On Liberty", in 1859: "Over himself, over his own mind and body, the individual is sovereign [...] The only purpose for which power can be rightfully exercised over any member of a civilized community, against his will, is to prevent harm to others." (Mill, 1859).

When enslaved to drugs, the individual is discarding his most fundamental right: to control his own actions. With this in mind, it seems that individual human rights are incom- patible with drug abuse. Consequently, all officials belonging to the United Nations or to any other responsible organization have the moral, ethical and civil obligation to protect the human rights of each individual.

In 2004, the Council of the European Union made explicit reference to human rights, among other matters, in the preface to the EU Drugs' Strategy for 2005- 2012. "This new Drugs' Strategy is based first and foremost on the fundamental principles of EU Law and, in every regard, upholds the founding values of the Union, respect for human dignity, liberty, democracy, equality, solidarity, the rule of law and human rights. It aims to protect and improve the wellbeing of society and the individual, to protect public health, to offer a high level of security for the general public and to take a balanced integrated approach to the drug problem" (General Secretariat, 2004).

It seems clear that drug abuse aggravates social and emotional misery and undermines human rights. By facilitating drug consumption, dependents like "Sandra" are being neglected and penalized. We could ask the people who have the goal of legalization and who use the argument of human rights to promote their position: would it (legalization) make drugs become less available? And would drugs become less attractive or less addictive as a result? Would legalization of drugs raise productivity and diminish road accidents? And what would be the impact on disease and crime? We don't need to be experts to understand that legalization, allowing the right to use drugs, would never be the best way to protect and improve the well-being of the individual and of the ones related to him.

Most people will agree that we have an obligation to protect young people and children, as The Declaration of the Rights of the Child promotes. That obligation includes protecting them from drugs, and from those who carry and use drugs. We must take care that the children, the citizens of tomorrow, not be threatened and harmed by the 'brave new world' of radical drug policies. 
We can read Aldous Huxley or think about Goethe's (1749-1832) pessimistic prescience anticipating the 'humanist medicalization'. He wrote: "I believe that in the end humanitarianism will triumph, but I fear that, at the same time, the world will become one big hospital, with each person acting as the other's nurse". (Szasz, 2003, p. 165). The question to ask then is whether this is the reality that we want to live within?

\section{Aknowledgments:}

It would not have been possible to write this letter in English without the support of Professor Neil McKeganey, BA, MSc, PhD, from the University of Glasgow. His help was precious, with his deep understanding of the subject and all its implications

\section{Conflict of Interests:}

I declare that I have no proprietary, financial, professional or other personal interest of any nature or kind in any product, service and/or company that could be construed as influencing the position presented in, or the review of this manuscript

\section{Funding:}

Nothing to declare

\section{REFERENCES}

Audibert, D., \& Araujo, R. (2009). Le pays où la drogue est légale. Le Point. Obtido de http://www.lepoint.fr/actualites-monde/200912-17/le-pays-ou-la-drogue-estlegale/924/0/405797

Beaumont, P., Townsend, M., \& Helm, T. (2010, Setembro 5). Britain looks at Portugal's success story over decriminalising personal drug use. The Guardian. Obtido de http://www.theguardian.com/politics/2010/se $\mathrm{p} / 05 /$ portugal-decriminalising-personal-druguse

DL 54/2013. Prevenção e proteção contra a publicidade e comércio das novas substâncias psicoativas, Pub. L. No. 54/2013 \$ Diário da República, 1. ${ }^{a}$ série - N. ${ }^{\circ} 75$ (2013).

European Monitoring Centre for Drugs and Drug Addiction. (2007). The state of the drug problem in Europe. Luxembourg: Office for Official Publications of the European Communities. Obtido de http://www.emcdda.europa.eu/publications/se archre-

sults? action $=$ list $\&$ type $=$ PUBLICATIONS $\&$ SE RIES PUB $=w 36$

European Monitoring Centre for Drugs and Drug Addiction. (2008). The state of the drug problem in Europe. Luxembourg: Office for Official Publications of the European Communities. Obtido de

http://www.emcdda.europa.eu/publications/se archre-

sults? action $=$ list $\&$ type $=$ PUBLICATIONS\&SE RIES PUB $=w 36$

European Monitoring Centre for Drugs and Drug Addiction. (2010). The state of the drug problem in Europe. Luxembourg: Publications Office of the European Union. Obtido de http://www.emcdda.europa.eu/publications/se archre-

sults? action $=$ list\&type $=$ PUBLICATIONS\&SE RIES_PUB $=w 36$

European Monitoring Centre for Drugs and Drug Addiction. (2011). The state of the drug problem in Europe. Luxembourg: Publications Office of the European Union. Obtido de http://www.emcdda.europa.eu/publications/se archre-

sults? action $=$ list $\&$ type $=$ PUBLICATIONS\&SE RIES PUB $=w 36$

Fernandes, T. (2009, Maio 7). Portugal inspira obama. Visão. Obtido de http://visao.sapo.pt/portugal-inspiraobama $=\mathrm{f} 509509$

General Secretariat. (2004, Novembro). EU Drugs Strategy (2005-2012). Apresentado na Council of the European Union, Brussels. Obtido de http://register.consilium.europa.eu/doc/srv? 1 $=\mathrm{EN} \& \mathrm{f}=\mathrm{ST} \% 2015074 \% 202004 \% 20 \mathrm{INIT}$

Gotz, W. (2009). Opening speech from EMCDDA's Executive Director. Apresentado na EMCDDA conference, Lisbon.

Greenwald, G. (2009). Drug Decriminalization in Portugal: Lessons for Creating Fair and Successful Drug Policies. Washington DC: CATO Institute.

Instituto da Droga e da Toxicodependência, I. P. (2007). A situação do país em matéria de drogas e toxicodependências (No. Relatório anual 2006). Lisboa: Instituto da Droga e da Toxicodependência, I.P. Obtido de http://www.sicad.pt/PT/Publicacoes/Paginas/ deta-

lhe. aspx?itemId $=15 \&$ lista $=$ SICAD_PUBLICA COES\&bkUrl=BK/Publicacoes/

Instituto da Droga e da Toxicodependência, I. P. (2008). A situação do país em matéria de drogas e toxicodependências (No. Relatório anual 2007). Lisboa: Instituto da Droga e da Toxicodependência, I.P. Obtido de http://www.sicad.pt/PT/Publicacoes/Paginas/ 
deta-

lhe.aspx? itemId $=15 \&$ lista $=$ SICAD_PUBLICA

COES\&bkUrl $=$ BK/Publicacoes/

Instituto da Droga e da Toxicodependência, I. P. (2009). Relatório de Actividades 2008. Lisboa: Instituto da Droga e da Toxicodependência, I.P. Obtido de http://www.sicad.pt/BK/Institucional/Instrum en-

tos/RelatoriosAtividade/Lists/SICAD_RELAT ORIOSATIVIDA-

DES/Attachments/4/Relat\%C3\%B3rio\%20de \%20Actividades\%202008A.pdf

Kerlikowske, G. (2010, Julho 29). Personal letter, Office of United States Drug Control Policy's Director.

Leshner, A. I. (1997). Introduction to the special issue: The National Institute on Drug Abuse's (NIDA's) Drug Abuse Treatment Outcome Study (DATOS). Psychology of Addictive Behaviors, 11(4), 211-215. http://doi.org/10.1037/0893-164X.11.4.211

Luppi, M., \& Barzanti, M. (sem data). San Patrignano - Institutional Communication. Obtido de http://www.sanpatrignano.org/en

Maia, S. (2009, Fevereiro 23). Muitos ficam «agarrados» à metadona para sempre. Diário de Notícias Portugal. Obtido de http://www.dn.pt/inicio/portugal/interior.asp $\mathrm{x}$ ? content_id $=1152093$ \&page $=-1$

McKeganey, N., Morris, Z., Neale, J., \& Robertson, M. (2004). What are drug users looking for when they contact drug services: abstinence or harm reduction? Drugs: Education, Prevention, and Policy, 11(5), 423-435.

http://doi.org/10.1080/096876304100017232 29

Mill, J. S. (1859). On Liberty. London: John W. Parker and son.

Office of National Drug Control Policy. (2010). Drug Decriminalization in Portugal: Challenges and Limitations. Washington DC: Executive Office of the President. Obtido de http://www.whitehouse.gov/sites/default/files
/ondcp/Fact_Sheets/portugal_fact_sheet_8 25-10.pdf

Peele, S. (1985). The Meaning of Addiction: Compulsive Experience and Its Interpretation. New York: Lexington Books.

Quintas, J. (2013, Março). Análise da experiência portuguesa da descriminalização do consumo de drogas. Apresentado na Grupo de Trabalho Toxicodependência e Álcool, Assembleia da República, Lisboa.

Sandra. (2004). Ex-drug dependent's personal report.

Szasz, T. S. (2003). Pharmacracy: Medicine and Politics in America. New York: Syracuse University Press.

Tavares, L. V., Graça, P. M., Martins, O., \& Asensio, M. (2004). Avaliação da Estratégia Nacional da Luta Contra a Droga 1999-2003 (Avaliação Externa e Independente da «Estratégia Nacional da Luta Contra a Droga» e do "Plano de Acção Nacional da Luta contra a Droga e a Toxicodependência - Horizonte 2004»). Oeiras: Instituto Nacional de Administração. Obtido de www.sicad.pt/BK/EstatisticaInvestigacao/.../R elatório_INA_final.pdf

The Economist. (2009, Agosto). Treating, not punishing. The Economist. Obtido de http://www.economist.com/node/14309861

United Nations General Assembly. Right of everyone to the enjoyment of the highest attainable standard of physical and mental health, Pub. L. No. A/65/255 (2010). Obtido de http://www.un.org/ga/search/view_doc.asp?sy $\mathrm{mbol}=\mathrm{A} / 65 / 255$

United Nations Office on Drugs and Crime. (2009). Annual Report 2008. New York: United Nations Publication. Obtido de http://www.unodc.org/unodc/en/frontpage/u nodc-launches-its-2008-annual-report.html

United Nations Office on Drugs and Crime. (2010). World Drug Report 2009. New York: United Nations Publication. Obtido de http://www.unodc.org/unodc/en/data-andanalysis/WDR-2009.html

Todo o conteúdo da revista Motricidade está licenciado sob a Creative Commons, exceto quando especificado em contrário e nos conteúdos retirados de outras fontes bibliográficas. 